\title{
ASSESSMENT OF THE IMPACTS OF TROUT FARMING ON WATER QUALITY USING MACRO INVERTEBRATES AS BIO- INDICATORS
}

\author{
A. Rai, A. Niraula, P. Ghimire, A. Pandey, A. Gurung, \\ C. M. Sharma and S. Gurung
}

Journal of Institute of Science and Technology

Volume 22, Issue 2, January 2018

ISSN: 2469-9062 (print), 2467-9240 (e)

Editors:

Prof. Dr. Kumar Sapkota

Prof. Dr. Armila Rajbhandari

Assoc. Prof. Dr. Gopi Chandra Kaphle Mrs. Reshma Tuladhar

JIST, 22 (2): 175-182 (2018)

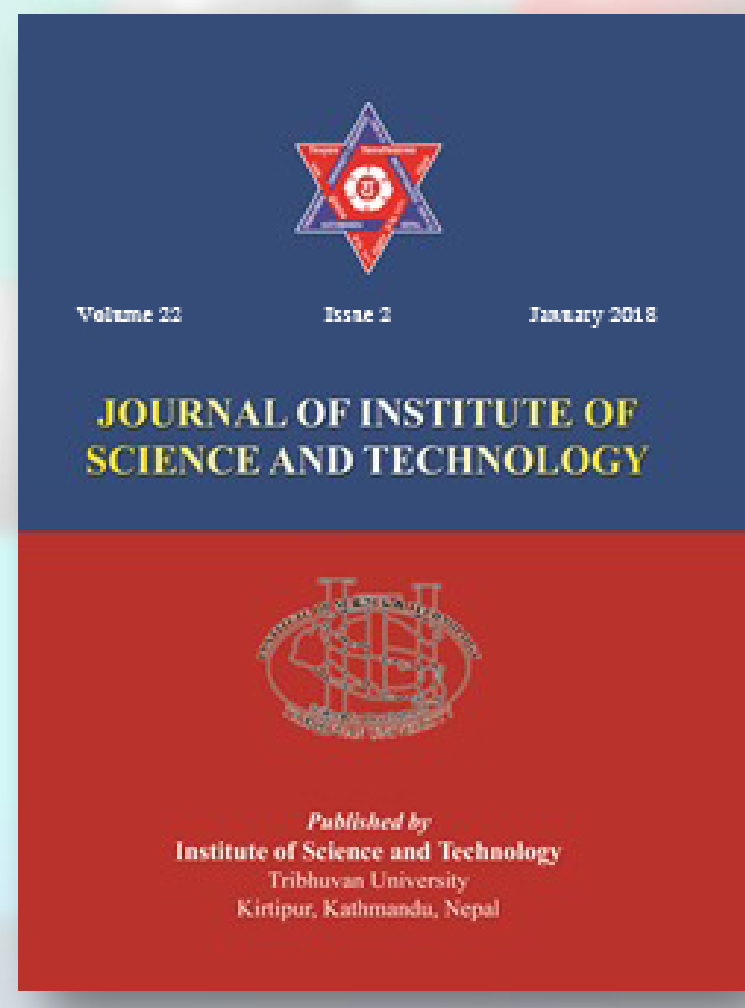

Published by:

Institute of Science and Technology

Tribhuvan University

Kirtipur, Kathmandu, Nepal 


\title{
ASSESSMENT OF THE IMPACTS OF TROUT FARMING ON WATER QUALITY USING MACRO INVERTEBRATES AS BIO- INDICATORS
}

\author{
Anuradha Rai, Archana Niraula, Payaswini Ghimire, Aastha Pandey, \\ Anu Gurung, Chhatra Mani Sharma and Smriti Gurung* \\ Department of Environmental Science and Engineering, School of Science, Kathmandu University \\ *Corresponding E-mail: smriti@ku.edu.np
}

Received: 10 April, 2017; Revised: 27 September, 2017; Accepted: 30 September, 2017

\begin{abstract}
The study was conducted to assess the impacts of trout farming on water quality using macro invertebrates as bio-indicators. Two trout farms were selected for the study, viz., Gandaki Trout Farm (GTF) in Kaski district and Fall \& Trout Fish Farm (FTF) in Nuwakot district. Reference and impacted sites were selected in each trout farms from where macro invertebrates were collected and physicochemical parameters were measured. Sorensen's Index and Multiple Site Similarity Index were calculated to compare the macro-invertebrate assemblages between the impact and the reference sites. Water quality classes were also calculated using macro invertebrate-based tool, NEPBIOS/ASPT scores. Altogether 24 families of macro invertebrates were observed at GTF and 12 families at FTF. The Sorensen's Similarity Index was greater than 0.5 between reference and impacted sites at GTF; whereas it was only 0.28 at FTF indicating comparatively low level of similarity. In addition, Multiple Site Similarity Index (0.64) at GTF also indicated high similarity between the macro invertebrate assemblages. Reference sites showed higher scores with higher diversity of macro invertebrates. Both farms had suitable water quality for trout (dissolved oxygen and temperature) and most of the physicochemical parameters did not show significant differences except $\mathrm{pH}$ and turbidity at GTF probably due to small scale operation and production.
\end{abstract}

Keywords: Trout farms, Water quality, Macro invertebrates, Bio-indicators, Sorensen's index.

\section{INTRODUCTION}

Fish farms and aquaculture are one of the fastest growing food industries in the world as they have proven to be a reliable source of fish for consumption (Mainstone et al., 1989; FAO, 2014). Rainbow trout (Oncorhynchus mykiss) are considered as one of the most popular cultured fish species (FAO, 2014) which are unique among carnivorous fishes and are natives of rivers draining into the Pacific Ocean (Boughton et al., 2006). They survive only in cold running waters requiring high protein feeds and well oxygenated water (MOAD, 2013). Trout culture has become an established tourism industry throughout the world in terms of consumption as well as recreational fishing (Barrington, 1983). Rainbow trout was introduced in Nepal only in 1969 from India and in 1971 from the United Kingdom and had to be re-introduced again from
Japan in 1988 (Swar, 2008). Rainbow trout farming has become popular in the country and is practised over several hilly districts of Nuwakot, Rasuwa, Kathmandu, Lalitpur, Dolakha, Sindhupalchowk, Kavrepalanchowk, Makwanpur, Dhading, Kaski and Mustang (MOAD, 2013).

Although fish farming has socio-economic benefits, it does have some environmental impacts as well (Namin et al., 2013). The impacts are from pollutants such as the uneaten feed, faecal matter, soluble metabolites and excretion of the fish farms (Kendra, 1991; Guilpart et al., 2012). These pollutants in turn alter water quality parameters such as Dissolved Oxygen (DO), Turbidity, Conductivity, Total Dissolved Solids (TDS), $\mathrm{pH}$ of the fish farms as well as other receiving water bodies (Noroozrajabi et al., 2013). Apart from these, consumption of fishes treated with drugs and residual chemicals may 
cause health impacts on humans too (Authman et al., 2015). Therefore, sustainable management of fish farming requires water quality assessment and monitoring of the fish farms and the receiving water bodies.

Routine water quality impact assessments of trout farming and aquaculture involve physicochemical as well as biological assessments (Noroozrajabi et al., 2013; Namin et al., 2013). The most common physico-chemical parameters used for aquaculture impact assessment in water bodies include $\mathrm{pH}$, temperature, dissolved oxygen (DO), electrical conductivity (EC), nitrate, and phosphate. A number of studies have revealed increase in the nitrate and phosphate concentrations and electrical conductivity at the inlets (Namin et al., 2013) and decrease in DO at the outlets (Kirkagaç et al., 2004). Additionally, macro-invertebrate assemblages have been used successfully for biological assessments in a number of studies (Namin et al., 2013; Kirkagaç et al., 2004). These studies have shown that the inlet and outlet assemblages differ with increase in the pollution tolerant taxa in the outlets. In Nepal, few studies have been conducted to assess the impacts of trout farming (Bhagat \& Barat, 2016) but specific studies using macro invertebrates as indicators to assess trout farming has not been conducted yet. Therefore, this study aims to assess the impacts on the water quality of the trout farms due to trout farming primarily focusing on macro invertebrates as bio indicators.

\section{MATERIALS AND METHODS}

\section{Study Area}

The study was carried out in two trout farms of Nepal- Gandaki Trout Farm (GTF) in Kaski and Fall \& Trout Village Fish Farm (FTF) in Nuwakot (Figure 1). Gandaki Trout Farm lies in Kaski district of Western Nepal in Sardikhola Village Development Committee (VDC) $\left(28^{\circ} 19^{\prime} 44.19^{\prime \prime} \mathrm{N}\right.$ and $\left.83^{\circ} 58^{\prime} 41.46^{\prime \prime} \mathrm{E}\right)$. The farm is one of the most successful trout farms in Kaski and is located within ACAP (Annapurna Conservation Area Project) region. The main source of water for this farm is the Bhurjung River (commonly called Bhurjung "khola"). Fall \& Trout Village Fish Farm is located in Kakani VDC within Nuwakot district $\left(27^{\circ} 48^{\prime} 50.48^{\prime \prime} \mathrm{N}\right.$ and $\left.85^{\circ} 13^{\prime} 13.93^{\prime \prime} \mathrm{E}\right)$. The source of water for this fish farm comes from a spring and the land used for trout culture is slightly sloped.

\section{Sampling Sites}

Three sampling sites were selected for GTF. The reference site for the GTF (Figure 2) was selected at the upstream of the farm $(1.5 \mathrm{~km}$ upstream) at Bhurjung Khola and the two impact sites (GTFI and GTFIM) were chosen downstream within the farm (Figure 2). GTFI was chosen to look at the impact on the artificial runway whereas GTFIM for the impact of the trout fishery on natural flow. In case of Fall \& Trout Village Fish Farm, only two sampling points were selected i.e. the Reference site (FTFR) upstream of the farm and the impact site (FTFIM) downstream of the raceways of the farm (Figure 3).

At each site, two macro invertebrate samples were collected and a composite sample was made. Therefore, a total of three composite samples from GTF and two composite samples from FTF were collected. In GTF, around $50 \mathrm{~m}$ stretch was considered at each sampling site.

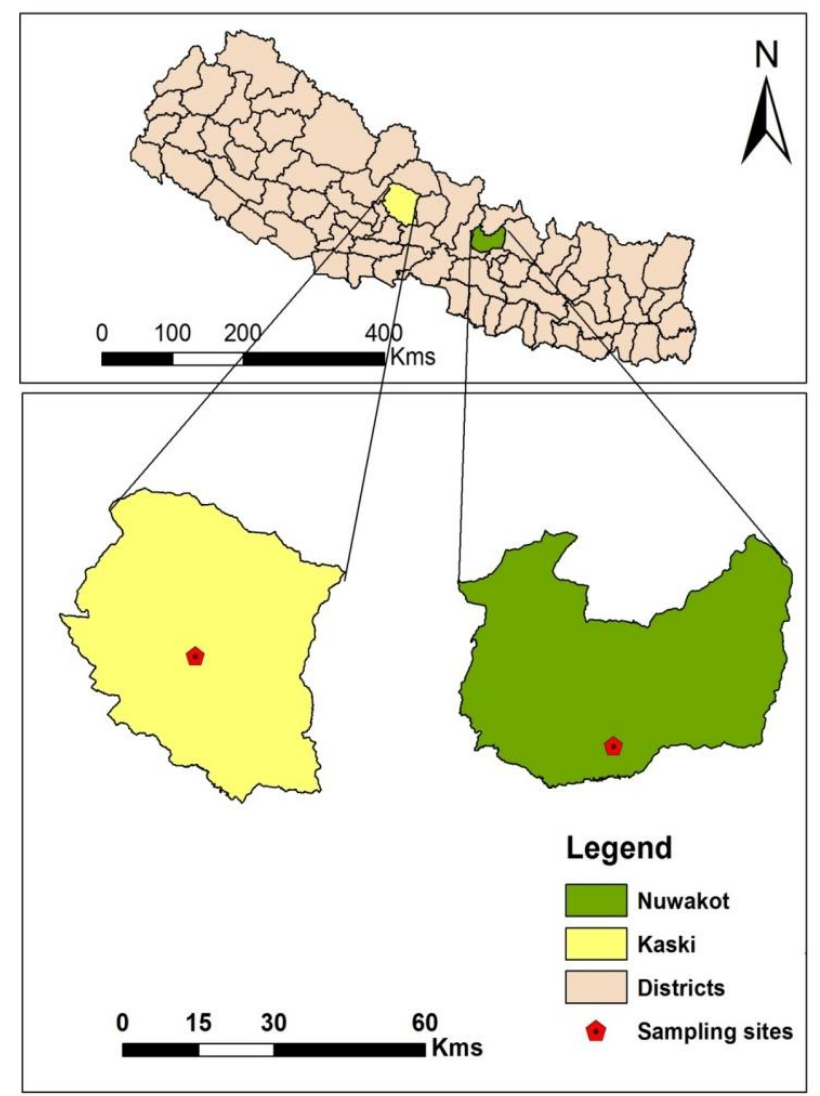

Fig. 1. Map showing the study sites. 


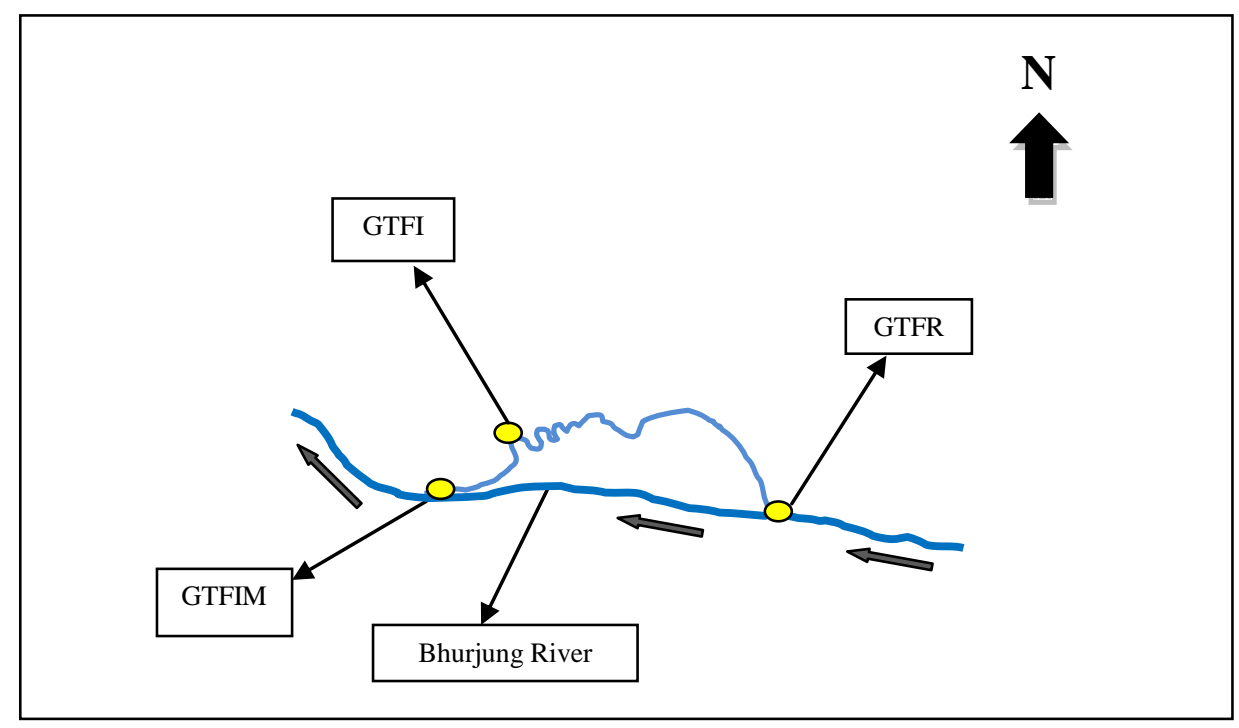

Fig. 2. Schematic diagram showing sampling sites of Gandaki Trout Farm.

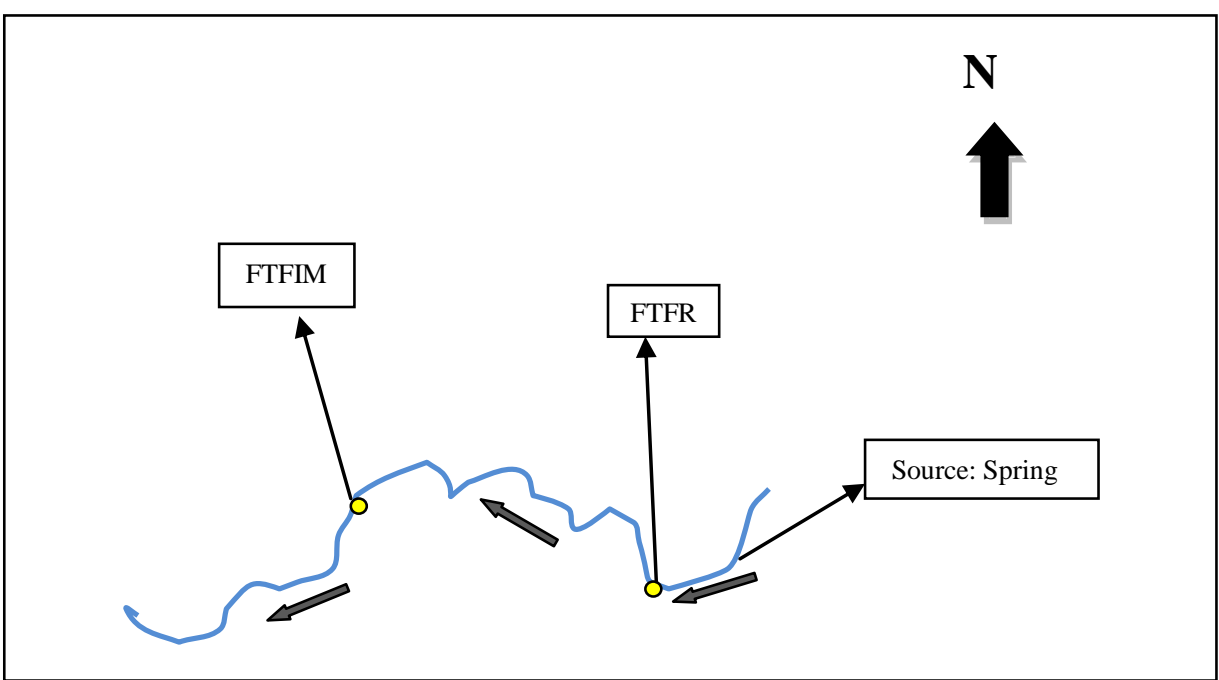

Fig. 3. Schematic diagram showing sampling sites of Fall and Trout Village Fish Farm.

\section{Sampling Method}

Sampling was conducted in the month of June, 2016. Selected physico-chemical parameters such as $\mathrm{pH}, \mathrm{DO}$, conductivity, TDS, turbidity and temperature were measured on site using a portable kit (WagTech). Macro invertebrates were collected by Kick sampling method following Barbour (1999). The substrates were disturbed by kicking action using the heel to dislodge the macro invertebrates. Then the $250 \mu \mathrm{m}$ mesh sized nets were used to trap the macro invertebrates. Some benthic invertebrates were also picked from submerged stones and wooden debris with the help of forceps. Collected macro invertebrates were sorted in the field and were preserved in $70 \%$ Ethanol for further identification.
The mean values of the physico-chemical parameters were calculated using Windows Excel. Mann Whitney Rank Sum test was conducted to look at the variation between the reference and the impact sites using Sigma Plot version 12.3.

The macro invertebrates were sorted and identified up to Family level following relevant literatures and identification keys (Merrit \& Cummins, 1996; Hartmann, 2007). The similarity between the macro-invertebrate assemblages of two sampling sites was assessed by calculating the Sorensen's Similarity Index which measures similarity in species composition for any two given sites (Magurran, 2004). This index can be calculated by using the following formula: 
Sorensen's Similarity Index $=\frac{2 C}{A+B}$

Where $\mathrm{C}=$ Number of Families that are common to the two sites undertaken

$\mathrm{A}=$ Number of Families in $1^{\text {st }}$ site

$B=$ Number of Families in $2^{\text {nd }}$ site

The value of the Sorenson's Similarity Index ranges between 0 to 1 . Values close to 1 indicate higher similarity and values close to 0 indicate lower similarity in assemblages from two sites (Magurran, 2004; Chao et al., 2006) whereas 0 means no similarity and 1 means complete similarity between assemblages of two sites.

Similarly, the similarity between the macro invertebrate assemblages of three sampling sites was assessed by calculating the Multiple Site Similarity Index which measures similarity in species composition for any given sites (Diserud $\&$ Ǿdegaard, 2007). The index can be calculated using the following formula:

$$
C_{S}^{T}=\frac{T}{T-1}\left(\frac{\sum_{i<j} a_{i j}-\sum_{i<j<k} a_{i j k}+\sum_{i<j<k<l} a_{i j k l}^{-\cdots}}{\sum_{i} a_{i}}\right)
$$

Where $a_{i}$ is the number of species in site $A_{i}, i=1, \ldots$, $\mathrm{T} ; \mathrm{a}_{\mathrm{ij}}$ is the number of species shared by sites $\mathrm{A}_{\mathrm{i}}$ and $A_{j}$; and $a_{i j k}$ is the number of species shared by sites $A_{i}, A_{j}$ and $A_{k}$ etc. and the value ranges from $0-1,1$ indicating complete similarity and 0 indicating no similarity (Diserud \& Ǿdegaard, 2007).

Water Quality Class (WQC) was calculated using NEPBIOS/ASPT (Nepalese Biotic Score/Average Score Per Taxon) (Sharma, 1996). This is a macro invertebrate-based tool where scores ranging from 1-10 are given to around 80 macro-invertebrate Families. Higher scores are given to pollution sensitive taxa whereas lower scores are assigned to pollution tolerant taxa (Sharma, 1996). The NEPBIOS/ASPT value is calculated by dividing the total scores of the organisms by the total number of taxa present at a particular sampling site as shown below:

$N E P B I O S / A S P T=\frac{\sum_{1}^{i} \text { NEPBIOS } \text { Score }_{i}}{\text { Number of taxa }}$

From the obtained NEPBIOS/ASPT values, WQC is calculated using the transformation table (Table 1).

Table 1: Transformation table and corresponding water quality class.

\begin{tabular}{lllll}
\hline $\begin{array}{c}\text { Water Quality } \\
\text { Class (WQC) }\end{array}$ & $\begin{array}{c}\text { NEPBIOS/ASPT } \\
\text { Original scale }\end{array}$ & $\begin{array}{c}\text { NEPBIOS/ ASPT } \\
\text { for midland }\end{array}$ & $\begin{array}{c}\text { NEPBIOS/ ASPT } \\
\text { for lowland }\end{array}$ & Description \\
\hline I & $8.00-10.00$ & $7.50-10.00$ & $6.50-10.00$ & Not Polluted \\
I-II & $7.00-7.99$ & $6.51-7.49$ & $6.00-6.49$ & Slightly Polluted \\
II & $5.50-6.99$ & $5.51-6.50$ & $5.00-5.99$ & Moderately Polluted \\
II-III & $4.00-5.49$ & $4.51-5.50$ & $4.00-4.99$ & Critically Polluted \\
III & $2.50-3.99$ & $3.51-4.50$ & $2.50-3.99$ & Heavily Polluted \\
III-IV & $1.09-2.49$ & $2.01-3.50$ & $1.01-2.49$ & Very Heavily \\
& & & & Polluted \\
IV & 1.00 & $1.00-2.00$ & 1.00 & Extremely Polluted \\
\hline
\end{tabular}

(Source: Sharma, 1996)

\section{RESULTS AND DISCUSSION}

\section{Physico-chemical parameters}

The results of the on-site estimation of the selected physico-chemical parameters are given in Table 2.

DO, conductivity and TDS did not show significant variation $(p<0.05)$ between the reference and the impact sites in both trout farms. Although DO was higher in the reference sites, conductivity and TDS were higher in the impact sites (except at GTFIM where conductivity and TDS were lower at the impact site) that could be due to increased dissolved salts from the seeds (Ghimire et al., 2017). pH was lower and turbidity was higher in the impact sites than the reference site in both farms. However, Mann Whitney Rank Sum Test showed a significant variation $(\mathrm{p}<0.05)$ in $\mathrm{pH}$ and turbidity only at GTF. 
Table 2: Physico-chemical parameters in two trout farms (GTF and FTF)

\begin{tabular}{llllllll}
\hline Site & Site Code & $\begin{array}{l}\text { DO } \\
(\mathbf{m g} / \mathbf{L})\end{array}$ & $\begin{array}{l}\text { Turbidity } \\
(\mathbf{N T U})\end{array}$ & $\mathbf{p H}$ & $\begin{array}{l}\text { Conductivity } \\
(\boldsymbol{\mu S} / \mathbf{c m})\end{array}$ & TDS $(\mathbf{p p m})$ & $\begin{array}{l}\text { Temperature } \\
\left({ }^{\mathbf{O}} \mathbf{C}\right)\end{array}$ \\
\hline Kaski & GTFR & $9.7 \pm 1.32$ & $0.7 \pm 0.76$ & $8 \pm 0.11$ & $163.5 \pm 40.16$ & $84.1 \pm 23.54$ & $20.7 \pm 2.72$ \\
& GTFI & $9.2 \pm 0.26$ & $1.7 \pm 0.48$ & $7.9 \pm 0.06$ & $202.4 \pm 1.89$ & $100.8 \pm 0.60$ & $18.6 \pm 0.43$ \\
& GTFIM & $10.4 \pm 0.14$ & $8.6 \pm 2.84$ & 7.8 & 148.4 & 72.7 & $19.7 \pm 0.14$ \\
\multirow{2}{*}{ Nuwakot } & FTFR & $11.2 \pm 0.84$ & $0.5 \pm 0.03$ & $7.6 \pm 0.12$ & $38.7 \pm 1.69$ & $19.4 \pm 0.77$ & $18.3 \pm 0.83$ \\
& FTFIM & $8.8 \pm 1.35$ & $3.2 \pm 1.66$ & $7 \pm 0.12$ & $43.2 \pm 1.34$ & $21.7 \pm 0.56$ & $19.8 \pm 3.02$ \\
\hline
\end{tabular}

$* \mathbf{p}<0.05$

$\mathrm{DO}, \mathrm{pH}$, and water temperature are of crucial importance for the abundance of rainbow trout (Swales, 2006). They require high DO concentrations (Matthews \& Berg, 1997) and concentrations greater than $7 \mathrm{mgL}^{-1}$ is considered optimum for their survival (Raleigh et al., 1984). Temperatures below $21^{\circ} \mathrm{C}(18.3 \pm 0.83$ to $20.7 \pm 2.72$ $\left.{ }^{\circ} \mathrm{C}\right)$ and high $\mathrm{DO}$ values $(8.8 \pm 1.35$ to $11.2 \pm 0.84$ $\mathrm{mgL}^{-1}$ ) in the studied fish farms indicate optimal conditions for the growth and survival of rainbow trout. The water for farming was brought to the farms through pipes with high velocity thereby facilitating mechanical aeration which could have attributed to higher DO values (Pulatsu et al., 2004, Boaventura et al., 1997). The $\mathrm{pH}$ in the study area was alkaline $(7 \pm 0.12$ to $8 \pm 0.11)$ and similar findings have been reported in other trout farms as well (Kirkagaç et al., 2004; Namin et al., 2013). Similarly, increase in turbidity in water bodies due to trout farming has also been reported in Iran too (Namin et al., 2013; Noroozrajabi et al., 2013). Increase in TDS and total suspended solids (TSS) in fish farms are from uneaten fish feed and the faecal matters of the fish (Guilpart et al., 2012).

\section{Macro invertebrate assemblages}

A total of 27 Families of macro invertebrates belonging to 10 Orders were observed from five sampling sites of the two investigated farms (Table $3 a$ and $3 b$ ).

Table 3a: Macroinvertebrate Families from Gandaki Trout Farm.

\begin{tabular}{ll}
\hline Site Codes & Macroinvertebrate Families \\
\hline GTFR* & Elmidae, Dryopidae, Chironomidae, Simuliidae, Limoniidae, Baetidae, Ephemerellidae, \\
& Heptageniidae, Leptoceridae, Hydropsychidae, Stenopsychidae, Uenoidae, \\
& Philopotamidae, Gomphidae, Perlidae, Capniidae. \\
GTFI & Elmidae, Dryopidae, Chironomidae, Simuliidae, Limoniidae, Ceratopogonidae, Baetidae, \\
& Ephemerellidae, Planorbidae, Hydropsychidae, Planariidae, Sphaeriidae. \\
GTFIM & Elmidae, Dryopidae, Chironomidae, Simuliidae, Limoniidae, Muscidae, Baetidae, \\
& Ephemerellidae, Caenidae, Planorbidae, Lymnaeidae, Mesovallidae, Hydropsychidae, \\
& Planariidae. \\
\hline
\end{tabular}

*Bhurjung Khola

Table 3b: Macroinvertebrate Families from Fall and Trout Village Fish Farm.

\begin{tabular}{ll}
\hline Site Code & Macroinvertebrate Families \\
\hline FTFR $* *$ & Elmidae, Gyrinidae, Chironomidae, Limoniidae, Baetidae, Ephemeridae, Leptophlebiidae, \\
& Hydropsychidae, Philopotamidae, Gomphidae, Perlidae. \\
FTFIM & Chironomidae, Hydropsychidae, Planariidae. \\
\hline
\end{tabular}


The total number of macro invertebrate Families observed at GTF was 24 and at FTF were 12. Insect fauna formed the bulk of the macroinvertebrate assemblages with 23 Families in contrast to the non-insect fauna which was represented by only four families of Mollusca (Planorbidae, Lymnaeidae, Planariidae and Sphaeriidae). At GTF, site GTFR had the highest diversity with 16 macro invertebrate Families followed by site GTFIM (14 Families) and GTFI (12 Families) (Table 3a). Similarly, at FTF, the reference site FTFR was found to have more number of macro invertebrate Families (11 Families) in contrast to only three Families in the impact site (Table 3b). In both the farms, the reference sites had the highest number of macro invertebrate Families (Table 3a and 3b).

The taxon Perlidae was found only in the reference sites of both the farms. This taxon is considered to be pollution sensitive and is typical of cold running waters with high DO concentrations (DeWalt et al., 2005). Chironomidae, Planariidae and Simuliidae were observed in the impact sites which are considered as pollution tolerant taxa (Hatami et al., 2011) known to survive in low DO concentrations (Kirkagaç et al., 2004). In contrast, the abundance of pollution sensitive taxa such as Hydropsychidae and Philopotamidae have decreased in the impact sites in both the farms. The abundance of pollution sensitive and pollution tolerant taxa in the reference and impact sites respectively from our study have also been reported elsewhere (Namin et al., 2013) The Sorenson's Similarity Index value of 0.57 (between GTFR and GTFI) and 0.53 (GTFR and GTFIM) are almost equal indicating a comparatively similar composition of macro invertebrate assemblages in the impact sites and the reference sites. The highest Sorensen's similarity index value of 0.76 was observed between GTFI and GTFIM indicating a comparatively higher similarity in assemblages between the impact sites. Similarly, the Sorensen's similarity index between the macro invertebrate Families observed at two sites (FTFR and FTFIM) of FTF was found to be 0.28 suggesting a comparatively low level of similarity of macro invertebrate assemblages between these two sites (Krebs, 2014). The Multiple Site Similarity Index (Table 4) between the macro invertebrate families observed at three sites of GTF was found to be 0.64 suggesting a high similarity between the assemblages.

Table 4: Table showing the similarity indices between Macro invertebrate Families observed at different sites.

\begin{tabular}{ll}
\hline Site Combinations & Similarity Indexes \\
\hline GTFR, GTFI \& GTFIM & 0.64 (Multiple Site Similarity Index) \\
GTFR \& GTFI & 0.57 (Sorenson's Similarity Index) \\
GTFR \& GTFIM & 0.53 (Sorenson's Similarity Index) \\
GTFI \& GTFIM & 0.76 (Sorenson's Similarity Index) \\
FTFR \& FTFIM & 0.28 (Sorenson's Similarity Index) \\
\hline
\end{tabular}

\section{Water quality}

The result of the NEPBIOS/ASPT scores and corresponding WQC and water quality of the sites is given in Table 5.

The overall Water Quality Class ranged from I-II to II-III (Table 5). The NEPBIOS/ASPT score of site GTFR is 6.42 which indicate that the Water Quality Class (WQC) is II. Similarly, the WQC of sites GTFI, GTFIM and FTFIM are found to be II-III and site FTFR has the WQC of I-II. On the basis of NEPBIOS/ASPT scores, the WQC distribution shows that the water of site GTFR is moderately polluted; sites GTFI, GTFIM and FTFIM have similar water quality and are found to be critically polluted whereas the site FTFR is slightly polluted. The NEPBIOS/ASPT scores of the sampling sites showed that the water of the impact sites was more polluted than that of the reference sites. 
Table 5: Table showing the Water Quality and Water Quality Class of different sites using NEPBIOS/ ASPT scores.

\begin{tabular}{llll}
\hline Site Code & NEPBIOS/ASPT Score & Water Quality Class & Water Quality \\
\hline GTFR & 6.42 & II & Moderately polluted \\
GTFI & 5.45 & II-III & Critically polluted \\
GTFIM & 5.3 & II-III & Critically polluted \\
FTFR & 7.27 & I-II & Slightly polluted \\
FTFIM & 4 & II-III & Critically polluted \\
\hline
\end{tabular}

\section{CONCLUSION}

The impact of trout farming on water quality based on physico-chemical parameters was not significant although small differences were observed in the outlets. In contrast, macro invertebrate assemblages differed in the reference and the impact sites and the difference was more pronounced in Fall and Trout Farm. Nevertheless, impacts detected in this study were not severe probably due to small scale production of the fish farms.

\section{REFERENCES}

Authman, M. M. N.; Zaki, M. S.; Khallaf, E. A. and Abbas, H. H. (2015). Use of fish as bioindicator of the effects of heavy metals pollution. Journal of Aquaculture Research \& Development, $6 \quad$ (4): 328. doi:10.4172/2155-9546.1000328.

Barbour, M. T.; Gerristen, J; Snyder, B. D. and Stribling, M. J. B. (1999). Rapid Bioassessment Protocols for Use in Streams and Wadable Rivers: Periphyton, Benthic Macro invertebrates and Fish. Second Edition, EPA, Office of Water, Washington DC.

Barrington, R. (1983). Making and Managing a Trout Lake. Fishing News Books, England, pp. 135.

Bhagat, R. P. and Barat, S. (2016). Endogenous feeding period of Rainbow trout, Oncorhynchus mykiss (Walbaum) in the raceways of Kathmandu, Nepal. International Journal of Pure \& Applied Bioscience, 4 (6): 123-135.

Boaventura, R.; Pedro, A. M.; Coimbra, J. and Lencastre, E. (1997). Trout farm effluents: characterization and impact on the receiving streams. Environmental Pollution, 95 (3): 379-387.

Boughton, D. A.; Adams, P. B.; Anderson, E., Fusaro, C.; Keller, E.; Kelley, E. et al.
(2006). Steelhead of the SouthCentral/Southern California Coast: Population characterization for recovery planning. U.S. Department of Commerce, NOAA Technical Memorandum, NMFS, Santa Cruz, CA, NOAA-TM-NMFSSWFSC-SC-394. pp. 116.

Chao, A.; Chazdon, R. L.; Colwell, R. K. and Shen, T. J. (2006). Abundance-based similarity indices and their estimation when there are unseen species in samples. Biometrics, 62 (2): 361-371

DeWalt, R. E.; Favret, C. and Webb, D. W. (2005). Just how imperiled are aquatic insects? A case study of stoneflies (Plecoptera) in Illinois. Annals of Entomological Society of America, 98 (6): 941-950.

Diserud, O. H. and Ǿdegaard, F. (2007). A multiple-site similarity measure. Biology Letters, 3 (1): 20-22.

FAO (2014). The State of World Fisheries and Aquaculture, Opportunities and challenges, Rome. pp. 3-7.

Ghimire, P.; Niraula, A.; Rai, A.; Pandey, A.; Gurung, S. and Sharma, C. M. (2017). Assessment of physico-chemical parameters of rainbow trout farms for the evaluation of potential threat to natural streams in Nepal. International Journal of Environment, 6 (2): 43-55.

Guilpart, A.; Roussel, J. M.; Aubin, J.; Caquet, T.; Marle, M. and Bris, H. L. (2012). The use of benthic invertebrate community and water quality analyses to assess ecological consequences of fish farm effluents in rivers. Ecological Indicators, 23: 356-365.

Hartmann, A. (2007). Field key for Selected Benthic Invertebrates from the HKH Region. Draft Report:Development of an Assessment 
System to Evaluate the Ecological Status of Rivers in the Hindu Kush-Himalaya Region (ASSESS HKH). pp. 35.

Hatami, R.; Soofiani, M.; Ebrahimi, E. and Hemami, M. (2011). Evaluating the aquaculture effluent impact on macro invertebrate community and water quality using BMWP index. Journal of Environmental Studies, 37 (59): 13-15.

Kendra, W. (1991). Quality of salmonid hatchery effluents during a summer low-flow season. Transactions of the American Fisheries Society, 120 (1): 43-51.

Kirkagaç, M. U.; Pulatsü, S. and Köksal, G. (2004). Effects of land based trout farms on the benthic macro invertebrate community in a Turkish Brook. The Israeli Journal of Aquaculture- Bamidgeh, 56 (1): 59-67.

Krebs, C. J. (2014). Ecological Methodology. Third Edition, Addison-Wesley Educational Publishers Inc. pp. 655.

Magurran, A. E. (2004). Measuring Biological Diversity. Blackwell Science Ltd. pp. 215.

Mainstone, C.; Lambton, S.; Gulson, J. and Seager, J. (1989). The Environmental Impact of Fish Farming- A Review. Water Research Centre, Medmenham, Buckinghamshire, SL7 2HD. pp. 104.

Matthews, K. R. and Berg, N. H. (1997). Rainbow trout responses to water temperature and dissolved oxygen stress in two southern California stream pools. Journal of Fish Biology, 50: 50-67.

Merritt, R. W. and Cummins, K. W. (1996). An introduction to the aquatic insects of North America. Third edition, Kendall/Hunt Publishing Company, Dubuque, Iowa.

MOAD (2013). Value Chain Development Plan for Rainbow Trout. Kathmandu: Ministry of
Agriculture Development, Government of Nepal. pp. 74

Namin, J. I.; Sharifinia, M. and Makrani, A. B. (2013). Assessment of fish farm effluents on macro invertebrates based on biological indices in Tajan River (north Iran). Caspian Journal of Environmental Sciences, 11 (1): 29-39.

Noroozrajabi, A.; Ghorbani, R.; Abdi, O. and Nabani, E. (2013). The impact of rainbow trout farm effluents on water physicochemical properties of Daryasar Stream. World Journal of Fish and Marine Sciences, 5 (3): 342-346.

Pulatsu, S.; Rad, F.; Köksal, G.; Aydin, F.; Benli, A. C. K. and Topçu, A. (2004). The impact of rainbow trout farm effluents on water quality of Karasu Stream, Turkey. Turkish Journal of Fisheries and Aquatic Science, 4: 9-15.

Raleigh, R. F.; Hickman, T.; Solomon, R. C. and Nelson, P. C. (1984). Habitat Suitability Information: Rainbow trout; US Fish and Wildlife Service FWS/OBS-82/10. 60: 1-64.

Sharma, S. (1996). Biological assessment of water quality in the rivers of Nepal. $\mathrm{Ph} . \mathrm{D}$. Thesis, University of Agriculture, Forestry and Renewable Resources, Vienna, Austria.

Swales, S. (2006). A review of factors affecting the distribution and abundance of rainbow trout (Oncorhynchus mykiss Walbaum) in lake and reservoir systems. Lake and Reservoir Management, 22 (2): 167-178.

Swar, D. B. (2008). History of rainbow trout (Oncorhynchus mykiss) introduction in Nepal: In TB Gurung (ed) Proceedings of the Workshop on Scaling-up of Rainbow Trout (Oncorhynchus mykiss) Farming Strategies in Nepal. Fisheries Research Division, Nepal Agricultural Research Council (NARC), Kathmandu. pp. 21-24. 